American Journal of Pharmaceutical Education 2019; 83 (7) Article 7567.

\title{
COMMENTARY
}

\section{Bringing to Light the Risk of Food and Housing Insecurity in Pharmacy Students}

\author{
Lauren Schlesselman, PharmD, MA Ed Psych \\ Center for Excellence in Teaching and Learning, University of Connecticut, Storrs, Connecticut \\ Associate Editor, American Journal of Pharmaceutical Education, Arlington, Virginia
}

Submitted February 20, 2018; accepted March 4, 2018; published September 2019.

Keywords: empathy, at-risk students, food insecurity, housing insecurity

As schools work to address student well-being, addressing food insecurity, defined as the inability to obtain a sufficient amount of affordable and nutritious food, ${ }^{1}$ and housing insecurity are not issues many pharmacy educators have considered in that equation. As more students attend college and the price of attending skyrockets, the students in our classrooms are in greater need of financial support to fund college and support their basic needs. While pharmacy educators realize that pharmacy students often graduate with significant debt as a result of taking out student loans, we are not always fully aware of the resource challenges students face while in school.

Interestingly, at the University of Connecticut (UConn) a group of students founded the UConn Access to Food Effort to address food insecurity and student hunger on campus. ${ }^{2}$ Through their project, backed by a UConn IDEA grant that supports student designed and led projects, the students gathered research evidence on student food insecurity at UConn, implementing solutions, and engaging in advocacy to address the issue. As part of their project, they surveyed more than 1,400 students, faculty members, and staff members about their food availability. The results showed that in the past year $25 \%$ had worried that they would not have enough food to eat because of lack of money, and $45 \%$ were unable to eat nutritious food because they lacked the resources to buy it. Thirty percent had to skip meals at some time in the past year because they did not have money.

The results at UConn are not unique. A study published in 2018 found 40\% of University of California students reported having food insecurity in the past year. ${ }^{3}$ The prevalence was highest among Hispanic and black students. Students with food insecurity were significantly more likely to be receiving financial aid and/or needbased grants or loans or to suspend their studies because of financial hardship. These students also had a lower

Corresponding Author: Lauren Schlesselman, University of Connecticut, 368 Fairfield Way, Unit-4001, Storrs, CT 06357. Tel: (860) 486-3402. Email: lauren.schlesselman@uconn.edu. cumulative grade point average (GPA) compared to food secure students. In a 2016 study at four public Illinois universities, $35 \%$ of students were considered food insecure, with $18.4 \%$ having very low food security. ${ }^{4}$ This study also found that food security status was significantly associated with race. African American students had the highest incidence of very low food security, while Caucasian students were associated with greater high food security. Student grade point averages (GPAs) were also associated with food security. Students with GPAs from 2.00 to 2.99 had more food insecurity than students in other GPA ranges. Students with student loans had more food insecurity than students receiving financial support that did not require repayment.

Despite the astonishingly high percentage of students who reported food or housing insecurity, these numbers may be lower than they actually are. Students who are homeless, housing insecure, and/or food insecure are often reluctant to share their living and food situation because they want to blend in with the rest of the student population. As a result, college officials may be unaware of the underlying reason for poor student retention, and therefore identify interventions that do not specifically address housing and/or food insecurity.

School administrators and faculty members should build awareness that there are students in their school dealing with housing insecurity and/or food insecurity. They should also develop awareness of the challenges and barriers these students face daily, along with the risks associated with housing and food insecurity. One aspect of the awareness message should include understanding the link between well-being and student success, followed by steps the school will take to address the needs of students with housing and food insecurity in order to ensure student retention and completion. Studies have shown that housing and food insecurity can impact academic performance. ${ }^{5,6}$ Students who experience food insecurity are at increased risk of poor academic achievement ${ }^{7}$ and delayed graduation. ${ }^{8}$ 


\section{American Journal of Pharmaceutical Education 2019; 83 (7) Article 7567.}

If we consider Maslow's hierarchy of need, we can understand why students facing housing and food insecurity can impact a student's ability to concentrate on academics. In his 1943 paper, "A Theory of Human Motivation," Abraham Maslow identified five hierarchical levels of needs. ${ }^{9}$ These needs are typically represented as a pyramid from the bottom of the hierarchy upward: physiological needs, safety needs, love and belonging needs, esteem needs, and self-actualization. Physiological (food, water, warmth, and rest) and safety (security) needs are often considered the basic needs. Belongingness and love (friends and relationships) and esteem (prestige and feeling accomplished) are considered psychological needs. Self-actualization relates to selffulfillment and achieving one's full potential. As described by Maslow, needs lower down on the hierarchy must be satisfied before individuals can attend to the higher needs. Originally he stated that lower needs must be completely satisfied before progressing on, but later clarified that a need did not need to be "satisfied 100 percent before the next need emerges." ${ }^{10}$ When basic needs are deficient, this deficiency motivates the individual until it is sufficiently met, with the motivation to fulfill these basic needs becoming stronger the longer they are denied.

Contrary to the thought that college students are protected from such deficiencies in basic needs because they are in a privileged and protective environment that provides housing and meal plans, students are not required to use university housing or purchase a meal plan. Given that pharmacy students are often students for more than four years, nontraditional students, or post-baccalaureate students, on-campus housing throughout their tenure is not always possible or feasible.

Even living on campus with a meal plan does not guarantee that a student's basic needs are met. As a mother of a high school senior who has spent the past year comparing institutions of higher education across the country, I have been amazed by the variations in meal plans. One institution offered on-campus students multiple meal plan options ranging from 10 meals per week to 21 meals per week. While the institution may have a rational reason for a 10 -meal option and that meal plan may be adequate in certain circumstances, the availability of such plans demonstrates that having a meal plan does not ensure students are provided enough food.

As I look out my window while students are heading to class, I am impacted by the possibility that one out of every four students who walks by could be struggling to focus on their academics because they are wondering where they will sleep tonight or when they will get their next meal. As we work to ensure student well-being, let us consider that food and housing insecurity may be impacting some of our students. Let us consider that the student sleeping in the classroom might have had nowhere to sleep last night. Let us imagine the feelings of shame and loneliness these students might experience. Let us work to develop awareness of the reality of this within our own schools. Let us ensure that compassion is shown to those who are struggling.

\section{REFERENCES}

1. Andersen S. Core indicators of nutritional state for difficult to sample populations. J Nutr. 1990;120(suppl 11): 1157S-1600S.

2. UConn Today. Student-driven Project Seeks to Address Food Insecurity on Campus. https://today.uconn.edu/2019/02/studentdriven-project-seeks-to-address-food-insecurity-on-campus/. Accessed February 19, 2019.

3. Martinez SM, Webb K, Frongillo EA, Ritchie LD. Food insecurity in California's public university system: what are the risk factors? $J$ Hunger Envir Nutr. 2018;13(1):1-18.

4. Morris LM, Smith S, Null DB. The prevalence of food security and insecurity among Illinois university students. J Nutr Educ Behav. 2016;48(6):376-382.

5. Hadley C, Crooks DL. Coping and the biosocial consequences of food insecurity in the 21 st century. Am J Phys Anthropol.

2012;149:72-94. doi:10.1002/ajpa.22161.

6. Jyoti DF, Frongillo EA, Jones SJ. Food insecurity affects school children's academic performance, weight gain, and social skills. J Nutr. 2005;135:2831-2839.

7. Patton-Lopez MM, Lopez-Cevallos DF, Cancel-Tirado DI, Vazquez L. Prevalence and correlates of food insecurity among students attending a midsize rural university in Oregon. J Nutr Educ Behav. 2014;46(3):209-214. doi:10.1016/j.jneb.2013.10.007.

8. Gallegos D, Ramsey R, Ong K. Food insecurity: is it an issue among tertiary students? High Educ. 2014;67:497-510. doi:10.1007/ s10734-013-9656-2.

9. Maslow AH. A Theory of Human Motivation. Psychl Review. 1943;50(4):370-396.

10. Maslow AH. Motivation and Personality. 3rd edition. New York, NY: Harper and Rowe; 1987. 